\title{
Actualizing the glamour concept in English advertising discourse
}

\author{
Y. V. Saraniuk
}

Taras Shevchenko National University of Kyiv, Ukraine

Paper received 04.11.17; Revised 07.11.17; Accepted for publication 08.11.17.

https://doi.org/10.31174/SEND-PH2017-145V41-10

\begin{abstract}
The article looks into English advertising texts in order to identify the way s the GLAMOUR concept is actualized in modern advertising discourse. The research focuses predominantly on the advertisements where the lexeme glamour and its derivatives are verbalized. Combining these lexemes with manipulative techniques is aimed at shaping in recipients the idea of glamour and at arousing the recipients' desire to purchase products labeled as glamorous.
\end{abstract}

Keywords: mass-media discourse, advertising discourse, function, GLAMOUR concept.

Glamour is one of the key concepts of modern culture, more precisely, of the layer which is formed by the media. Today the word 'glamour' is quite common in the advertising context, its main advertising idea being everything that culture endows with value - happiness, beauty, youth, health, material success, love, belonging to a prestigious social group - can be achieved through the purchase of the product.

In modern linguistic studies of mass-media discourse, it is customary to distinguish its various genres using the functional criterion as a basis for classification. The factual material reveals that the GLAMOR concept is actualized in the following genre varieties of English massmedia discourse: 1) journalistic discourse (this genre variety is distinguished by a number of researchers [7, $\mathrm{p}$. $17 ; 10$, p. 8]), 2) advertising discourse (we distinguish this genre kind after [7, p. 17; 10, p. 8]); 3) an entertaining show described as one with a status of a separate genre in $[10$, p. 10], 4) society columns (this genre variety has been substantiated by [6]). This article will consider the actualization of the GLAMOUR concept in one of the above-mentioned genres, i.e. advertising discourse.

A peculiarity of actualizing the GLAMOUR concept in advertisements is that advertisements promote an object with which the quality of glam is as sociated but not glamour as such. For example, the text "Michael Kors Geometric Glamor Solids Cold Shoulder Ruffle Dress Coverup" [13] advertises a glamorous summer dress with flounces on the shoulders, which is followed by the advertisement of a glam bracelet: "Michael Kors Glamorous Gold Canvas Tote Handbag" [2]. The reader's attention is primarily caught with the statement about the 'glamorousness' of these items.

Besides, the authors of such texts pursue another aim, that is, to convince the recipient that with the help of the advertised goods any woman will be glamorous. This argument may take an explicit verbal form, for example: "Vintage Glam Silver back a Sexy lingerie. This is hot and the style is unique and stunning. This will surely make you partner's head spin. This sexy set is worth grabbing. Get the glamorous look with this lingerie in no time" [12]. Here, the imperative Get the Glamorous Look with this lingerie in no time encourages a potential client to gain a glamorous look as a result of acquiring the product. The advertisement contains a verb in the imperative form of the verb to get that combines mean ings of contact establishment, purchase, searching, discovery and savings, which is meant to influence the target consumer's psyche in a covert way. This use of implicit suggestion is thought to be an effective marketing technique, since implicit information is readily perceived by the recipient and shapes attitudes to an advertised product (service). The text prompts the audience to believe that products described as can be used as a means of achieving glamour by the recipients of advertisement.

An exp licit promise of a glamorous look is found in the text "Pair these stylish hats with a simple, classic outfit and you'll instantly look like an Old Hollywood movie star! The Hat That Will Make You Instantly Glamorous This Spring" [11]. The author openly claims that by purchasing a stylish hat recipients will immediately transform themselves into a glamorous image.

The advertisement of Giorgio perfume "Giorgio: Fragrance That Makes You Feel Glamorous!" suggests that having purchased a product of this brand every woman will feel beautiful and glamorous adding that Giorgio perfume will be a nice gift for Mother's Day: “A gift for Mother's Day is something children want to be special for their mom!", "The fragrance that'll make her (mother) feel glamorous and makes her feel like an extraordinary woman in her children's eyes! Every woman wants to feel beautiful and smell good"'[8].

Interestingly, the main audience of the advertisement is still wo men, which proves the feedback by a blogger Tara Pitman who comments that using the [8] perfume brings a sense of satisfaction to the consumer: "The fragrance is very pleasant and subtle which I enjoyed. I love floral smells. This perfume is and will always be a classic!' She describes the pleasant physical state: the product doesn't irritate the olfactory receptors (When spraying a dab on my skin, I noticed it wasn't hard on the nose. It went very well with my body chemistry) and the psychological state: the feeling of extraordinariness, confidence in oneself (makes her feel like an extraordinary woman).

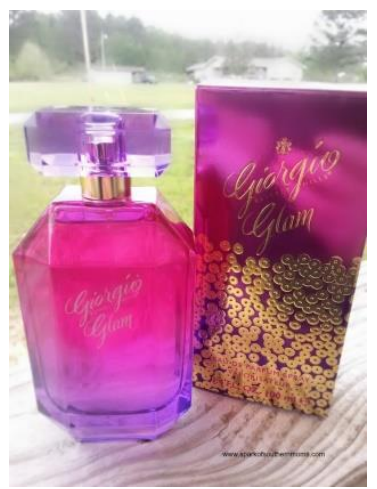

Pic. 1. Image to the advertisement under the name "Giorgio: Fragrance That Makes You Feel Glamorous!” [8].

Advertisements that actualize the GLAMOUR concept 
try to achieve a dual aim which determines the visual accompaniment of advertising messages. So, an image may be only and exclusively of a sole advertised item (a piece of jewelry, for example (see Pic. 1.). It is the case with the text "Glamorous and stunning chunky linked tennis bracelet in gold plated stainless steel made with SWAROVSKI ELEMENTS" [1] that goes together with the visual component. This technique reinforces the effect a particular glamorous product has on the target consumer. In this example the GLAMOUR concept is verbalized by the adjective glamorous. Here, the verbal component SWAROVSKI ELEMENTS implies a high price, on the one hand, and its exclusive and prestigious nature, on the other. Both of these are used in order to persuade the recipient of glamorous quality of the product and, consequently, of its necessity for a glamorous image.

Yet, a visual component of an ad can show a holistic glamorous image: a glamorous model (such as photo of a beautiful bride dressed in an advertised glamorous dress with a beautiful bouquet on an elegant sofa (see Pic. 2.), whose appeal is boosted with the text "Wow! What a beauty! The detail on this glam gown is amazing. beaded crystals scoopneck" [12]. In this example, the GLAMOUR concept is expressed by the adjective glam, which is shortened form of glamorous and is quite casual. The curtailed word creates an atmosphere of trustful communication with the recipient of the message. The exclamatory sentences expressing admiration (Wow! What a beauty!) are intended to arouse strong positive emotions in the recipient of this advertisement. In addition, positive evaluation of the advertised dress is emphasized with the adjective amazing. To top it all, the visual component of advertising (a beautiful photo (see Pic. 2.)) enhances the function of persuading the recipient to become glamorous at her wedding.

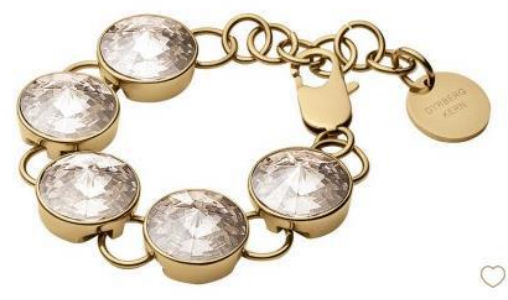

Pic. 2. Image to the advertisement under the name "Glamorous and stunning chunky linked tennis bracelet" [1].

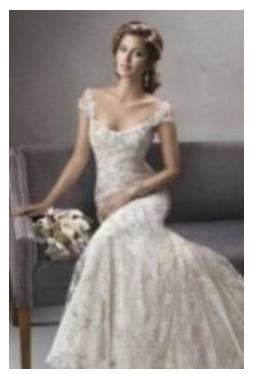

Pic. 3. Image to the advertisement under the name "Bride With Sass Wedding Dresses" [12].

Another function of the visual component in an advertisement may be to induce the recipient to believe it is highly necessary to become glamorous. For example, the advertising text under the caption "Glamorous Getaway
Tunic in Ivory" [3] contains the message "Glam up your casual collection with this pretty tunic! This cozy and soft cutie is perfect for a chilly day and will be sure to keep your style chic and cool!" [3]. The appreciation of the advertised tunic is expressed with the adjectives pretty, cozy, soft, cutie, perfect, chic, cool. The text is accompanied by a photo of a model dressed in the advertised clothing (see Pic. 3.).

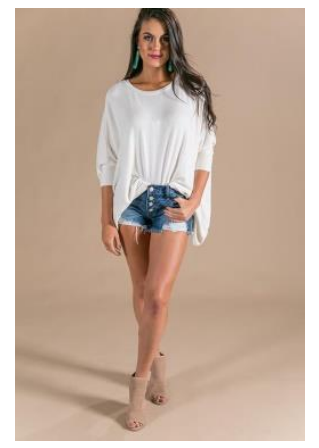

Pic. 4. The main image to the advertisement "Glamorous Getaway Tunic in Ivory" [3].

As a rule, in advertise ments, the non-verbal component plays quite an important role in the transmission of the message. As experts say, an illustration should attract attention of its target recipients, give them a certain idea of the product advertised, create a favorable impression and, in the end, make them buy it.

All in all, the research has revealed that advertisements where the GLAMOUR concept is objectified tend to perform a dual function: first, they promote a product and secondly, they promote glamour as a quality to be strived for. In this respect, different brands compete with one another, trying to sell their goods, which inevitably leads to their promoting glamour as a social and cultural phenomenon. This agrees with the fact that advertising media discourse inherently is designed to "create certain mindsets in the audience that induce it to carry out certain actions" [7, p. 19]: advertisements of glamorous products plant in its recipients the idea of glamour as desirable or even necessary feature in their lives and this desire encourages the purchase of glamorous goods and, consequently, "glamorization" of their image.

Depending on the price, a certain glamorous product may be available to a wider or a narrower circle of consumers. In an advertisement of a product affordable to a wide range of consumers, they are encouraged to buy this product with the help of a promise addressed directly to the recipient (which is the case in This is a real beauty! This amazing black dress in V neck is a charm and you will love it! This glamorous dress will get you praises and is perfect to flaunt the style" [12] where the second person pronoun you is used (This glamorous dress will get you praises).

If the cost of the goods is rather high, then the price should be justified to convince buyers that the product is worth the money. For example, the advertisement of lipstick "CHRISTIAN LOUBOUTIN CREATED THE MOST GLAMOROUS LIPSTICK EVER" [9] emphasizes that the best things are expensive: "At $\$ 90$ each, they don't come cheap, but the best things rarely do" [9].

When the cost of an advertised product or service is too high for the average consumer, as the cost of staying 
in a luxury hotel Muse Saint-Tropez ("Rooms begin at around USD \$1,228 a night" [5], then the glamour promotion becomes the dominant advertising technique, which is observed in the publication "Muse Saint-Tropez Captures the French Riviera's Laid-Back Glamour" [5]. Similarly, a publication about glamorous holidays in the best Australian zoos ("Go Glamping at Australia's Coolest Zoos" [4]) is unlikely to be used by many of its readers as a motivation but each reader will get an idea of glamour and develop the desire to get it: "If you didn't realize that staying at the zoo could be a luxurious event, think again! You may have not even known that some zoos have overnight accommodations; but these ones really represent the top of the line in glamping or luxury accommodations" [4].

Thus, glamour is promoted as a prestigious, socially desirable and appreciated quality in advertising discourse and advertising manifests itself as a means of producing glamorous images, that is, ideal images that express values and norms affecting the consumers' behavior and making them purchase goods.
1. Dyrberg/Kern "Glamorous and stunning chunky linked tennis bracelet" [E. resource] / Dyrberg/Kern - Access mode: https://www.dyrbergkern.com/anika.html

2. Ebay "Michael Kors Glamorous Gold Canvas Tote Handbag" [E. resource] / Ebay - Access mode: https://www.ebay .co.uk/p/Michael-Kors-Glamorous-GoldCanvas-Tote-Handbag-SHOPPER-Bag/1176258661

3. Impressions Online Boutique "Glamorous Getaway Tunic in Ivory" [E. resource] / Impressions Online Boutique - Access mode: https://www.shopimpressions.com/products/glamorousgetaway-tunic-in-ivory

4. JustLuxe "Go Glamping at Australia's Coolest Zoos" [E. resource] / JustLuxe - Access mode: http://www.justluxe.com/community/go-glamping-ataustralias-coolest-zoos_a_1964814.php

5. JustLuxe "Muse Saint-Tropez Captures the French Riviera's Laid-Back Glamour" [E. resource] / JustLuxe - Access mode: http://www.justluxe.com/travel/hotel/feature-1963051.php

6. Khalgaeva D. D. "Society Colums" as a genre of women's electronic magazines (on the material of Russian and English lan guages): Author's abstract. dis. ... cand. Philol. Sciences: 10.02.19 / D.D. Khalgaeva; Volgograd. state. sots.-ped. un-t. - Volgograd, 2015. - 26 p.

7. Kozhemyakin E. A. Mass communication and media discourse: to research methodology. Scientific statements of BelGU. Humanities Series, 2010, no. 12, vol. 6, pp. 13-21[E. resource] / E.A. Kozhemyakin - Access mode:

\section{FERENCES}

https://cyberleninka.ru/article/n/massovay a-kommunikatsiy ai-mediadiskurs-k-metodologii-issledovaniy a

8. Spark of Southern "Giorgio: Fragrance That Makes You Feel Glamorous!” [E. resource] / Spark of Southern - Access mode: http://www.sparkofsouthernmoms.com/giorgiofragrance-makes-feel-glamorous/

9. HarpersBAZAAR "Christian louboutin created the most glamorous lipstick ever” [E. resource] / HarpersBAZAAR Access mode: http://www.harpersbazaar.com/beauty/makeup/a11718/christi an-louboutin-lipstick/

10. Temnikova L. B. On the question of the typology of the media discourse // Polytematic network electronic scientific journal of the Kuban State Agrarian University. - 2016. - Issue. No. 119. - pp. 1-13. - [E. resource] / L.B. Temnikova Access mode: http://cyberleninka.ru/article/n/k-voprosu-otipologii-mediadiskursa

11. Viva Glam Magazine "The Hat That Will Make You Instantly Glamorous This Spring” [E. resource] / Viva Glam Magazine - Access mode: http://vivaglammagazine.com/the-hatthat-will-make-you-look-instantly-glamorous-this-spring/

12. Weddbook [E. resource] / Weddbook - Access mode: http://weddbook.com/search/glam

13. Zappos "Michael Kors Geometric Glamor Solids Cold Shoulder Ruffle Dress Cover-up" [E. resource] / Zappos Access mode: https://www.zappos.com/p/michael-michaelkors-geometric-glamour-solids-cold-shoulder-ruffle-dresscover-up-black/product/9029855/color/3

\section{Актуализация концепта GLAMOUR в рекламном дискурсе Е. В. Саранюк}

Аннотация. Статья посвящена анализу концепта GLAMOUR и особенностям его актуализации в современном англоязычном рекламном дискурсе. Исследование фокусируется преимущественно на анализе рекламных сообщений, в которых вербализируются лексема glamour и её дериваты. Сочетание этих лексем с манипулятивными приёмами направлено на создание у реципиента представления о гламуре и формирование стремления его получить с помощью приобретения товара, позиционируемого как гламурный.

Ключевые слова: массмедийньй дискурс, рекламный дискурс, функция, концепт GLAMOUR. 